\title{
Law Enforcement Against Transfer of Objects Fiduciary in Kudus Police
}

\author{
Agus Budianto ${ }^{1}$ and Umar Ma'ruf ${ }^{2}$
}

Abstract. The purpose is achieved in this research are: to know the mechanism of the occurrence of a credit agreement in the German Fiducia between Guarantees the lender with the leasing in the state law enforcement to know Grail in the event of a transfer of the object of the fiduciary guarantee in the region Police Resort of Kudus. To know the constraints in the legal enforcement of the related existence of a Fiduciary guarantee redirects object at Police Resort, and the solution for consumers.

This research is the legal research approach or using Empirical Juridical also called as the Juridical Sociological. This research is descriptive analytical research as specified.

Research results in the agreement between the creditors and the debtor financing mutual committing yourself, before making the deal, leasing the breathtaking debtor must meet the obligation to pay installments on a timely basis in accordance with the quantity and the date of the has been agreed, then release the rights and obligations not to a make problem. In terms of collateral object is the object of fiduciary transferred to third parties apply the principle creditors can still execute the collateral objects. The transfer of objects into objects fiduciary third parties does not preclude the right of creditors to keep executing the fiduciary guarantee object.

The conclusions in this study is on the implementation of the Business Funding and need the assistance of the police dai it will be very easy and possible to overcome the rogue debtor.

Keyword: Law Enforcement; The Transfer Object Fiduciary Guarantee; Fiduciary; Police Resort of Kudus

\section{Introduction}

Development of Indonesian Nation implemented refers to one of the Indonesian national goal of creating a just and prosperous of society based on the Constitution of 1945 , so all the construction carried out aimed at the welfare of society.

In order to function as a conduit of funds to the Community, the banking industry run their business to give credit to the customer (debtor), lending by banks basically should be based on confidence in the capability and capacity of debtors and storage community funds. It must be carried out, despite the fact that increasing bank credit is given to risk. ${ }^{3}$

Collateral material that is known in the legal system guarantees in Indonesia is Certificate Deed of Fiduciary Guarantee and formally issued by the Ministry of Justice and Human Rights. Fiduciary means the guarantee of moving goods belonging to

\footnotetext{
1 Student of Master of Law, Universitas Islam Sultan Agung Semarang and Entrepreneur: email: agusbudianto8889@gmail.com

${ }^{2}$ Faculty of Law Universitas Islam Sultan Agung

${ }^{3}$ Marulak Pardede dan Badan Pembinaan Hukum Nasional Departemen Hukum dan Hak Asasi Manusia RI, Penelitian Hukum Tentang Implementasi Jaminan Fidusia Dalam Pemberian Kredit Di Indonesia, Jakarta, 2008, p. 1.
} 
debtor bound by the credit agreement with a basic trust gives the position of the debtor to keep control of the collateral, although only as borrowers use to temporarily or no longer be the owner. This fiduciary certificate when linked with the provisions of Article 1152 of the Civil Code which regulates the material guarantee indeed seems very contrary to that article because according to article require that the collateral be physically handed over to the lender. The provisions of Article 1152.

Fiduciary guarantee the principles of droit de suite, the fiduciary still follow objects object rnenjadi fiduciary in hand anyone the object is, except transfer of the inventory objects that become the object of fiduciary

Furthermore, Article 23 paragraph (2) of the Act expressly prohibits Fiduciary giver to "divert", mortgage or lease to another party objects that become the object of fiduciary that is not an object of supplies, except with the prior written consent of the holder of fiducia.

In a fiduciary agreement object as object fiduciary is still in the control of the owner of the object (the debtor) and not controlled by the creditor, so in this case is the delivery of objects without giving up ownership of physical object. Creditors entrust to the debtor to remain biased use of objects such guarantee in accordance with its function. Associated with the transfer of the object fiduciary in any jurisdiction in Kudus police, it can be seen that the cases that have been handled by the Kudus Police, it has already to the courts, the decision, but there is nothing that can not be raised to the level of the court, this is because at the stage investigation, investigators are having trouble because of unknown whereabouts of suspects, so that it impedes the completion of the law.

This research took the formulation of the problem of the mechanism the occurrence of a credit agreement in the Fiduciary Security between creditor and leasing in Kudus regency law enforcement in case of transfer of fiduciary security object in the jurisdiction Kudus police and constraints in law enforcement related to the transfer of fiduciary security object in Kudus police and how the solution for consumers.

\section{Research methods}

This research is legal using empirical juridical approach or commonly referred to as the Juridical Sociological. Specifications research is a descriptive study.

The data collection can be performed using primary and secondary sources. Methods of data collection include literature study, observation and interviews. Informants in this study consisted of key informants and informants additional data on the issue of Law Enforcement Against Transfer of Objects Fiduciary In Kudus police, namely:

- Head of the General Criminal Investigation Unit of Kudus Police Resort;

- Investigators Criminal Police and General Police of the Kudus;

- Financing Institutions (Leasing) BFI

Methods of data analysis used in this research is descriptive and qualitative analysis, which is a way of analysis of the results of research that produce descriptive data analytical, that the data stated by the respondent in writing or orally as well as the behavior of the real, which is researched and studied as a whole. ${ }^{4}$

\footnotetext{
${ }^{4}$ Ibid, p.192.
} 


\section{Results and Discussion}

\subsection{The Mechanism of Occurrence of the Credit Agreement Between Creditors In Fiducia Guarantee With Leasing In Kudus District}

- Loans application by an institution is based on mutual trust, thus lending a gift of trust. This means that a new credit institution will grant credit if he really believe that the debtor will repay the loans received

- Survey (i) conducted by the Surveyor of the finance company for the purpose of comparing the data provided by the debtor's financial situation really is. It aims to determine the amount of monthly installments to be paid by the debtor.

- Credit analysis every credit application submitted by the debtor must be processed through further assessment and given decision. Rate manifested in the form of making credit analysis.

- Interviews were conducted to obtain information about the debtor by way of question and answer.

- A decision on the loan application

- Document print for prospective borrowers are approved, all documents will be prepared and submitted to the loan to be signed and sent to the filling data.

- The validation process in this process prescribed due date of payment installments that fall when credit is liquid or invalid. And at that time credited cars can already be used by the debtor.

- Filling document all the signed document was made in 4 are each sent to the debtor, the notary, the central office, and the one stored in the company as customer data.

Leasing financing agreement with fiduciary guarantee this in which there are surrender fiduciary property. The definition of fiduciary property submission here is that ownership over the collateral is BPKB on behalf of the debtor. The debtor retains the physical object as a borrower or debtor wearer up to meet all its obligations to creditors in accordance with the agreement.

\subsection{If the Law Enforcement There Fiduciary Transfer of Objects In Kudus police jurisdiction}

Law enforcement by Ten Berge said that the instrument of law enforcement include oversight and enforcement of sanctions, supervision is a preventive measure to impose decency, and the imposition of sanctions is a repressive measure to impose decency.

Fiduciary recipient preferences will have rights, namely the right to take over the receivables settlement proceeds from disposal of objects into the new preferences will fiduciary. Security Object Right acquired at the time of registration of the Fiduciary Registration Office and the Right is not clear because of the bankruptcy or liquidation Giver Fiduciary. If the receivables transferred to another party, then the debt guarantee Fiduciary also transferred to the transferee Fiduciary. So if for whatever reason, things Fiduciary is transferred to the hands of others, then the Fiduciary on the object is still valid and there is no obligation and the responsibility of the recipient of 
Fiduciary on fault (intent or negligence) of the Giver Fiduciary, which arises because the relationship contractual or due to an unlawful act, in connection with the use and transfer of objects into places such Fiduciary.

The debtor action is deemed to have embezzled the property of others, which may be subject to criminal charges of embezzlement Criminal Code Article 372 Penal Code with imprisonment forever 4 (four) years. Meanwhile, according to Article 23 paragraph (2) of the Law of Fiduciary mentioned that "fiduciary giver may assign, pledge, or lease to another party objects into an object that is not a fiduciary body except with the prior written consent of the recipient fiduciary". If these provisions are violated, it is based on Article 36 of Law fiduciary, fiduciary giver may be liable to imprisonment for a period of 2 (two) years and at most Rp. 50,000,000, - (fifty million).

\subsection{Constraints In Law Enforcement Related To The Transfer Of Fiduciary Security Object In Kudus Police Solution For Consumers}

Fill the financing agreement with the fiduciary is no mention that the creditor the right to withdraw if the customer vehicle negligent or did not make installment payments as appropriate provisions. However, in practice, this is rarely done because it is based on the consideration that the delay is not necessarily caused by the debtors themselves, but also enabled the fault of the administration. Therefore, before there should be efforts, including sending letters, announcements through the mass media, and the blocking vehicle registration and reg.

If these efforts do not succeed, then the withdrawal of the vehicle can be done out of court or through a court. Court settlement have been selected for the weaknesses inherent in the judiciary in resolving the dispute, both weaknesses that can be improved or not, so many people who want to find other ways to resolve disputes outside of court bodies.

In this case required the consensus of both sides agreed to resolve it out of court. If a case can not be settled amicably by the parties litigant, a last resort that can be reached is begging settlement through the court. Litigation proceedings is everything to do with the judicial process in the courts. Hiking litigation which in this litigation path is divided into two types namely lane Civil and Criminal lines. For civil paths taken through a process of a lawsuit. To that end, the plaintiff filed a suit against the head of the competent district court. The settlement is done by way of foreclosure.

\section{Closing}

\subsection{Conclution}

- The mechanism of occurrence of the Credit Agreement Between Creditors In Fiducia Guarantee With Leasing In Kudus include: Credit Application Credit granted by an institution is based on trust; The survey was conducted by the Surveyor of the finance company; Credit Analysis Every credit application submitted by the debtor must be processed through the assessment; Interviews were conducted to obtain information about the debtor by way of question and answer; $A$ decision on the 
Ioan application; Document print For prospective borrowers are approved; The validation process; Filling document.

- If The Law Enforcement There Fiduciary Transfer Of Objects In Kudus Police Jurisdiction

Fiduciary recipient preferences will have Rights, namely the right to take over the receivables settlement proceeds from disposal of objects into the new preferences will Fiduciary. Security Object Right acquired at the time of registration of the Fiduciary Registration Office and the Right is not clear because of the bankruptcy or liquidation Giver Fiduciary.

The debtor action is deemed to have embezzled the property of others, which may be subject to criminal charges of embezzlement Criminal Code Article 372 Penal Code with imprisonment forever 4 (four) years.

- Constraints in law enforcement related to the transfer of fiduciary security object in Kudus police and how solution for consumers

Fill the financing agreement with the fiduciary is no mention that the creditor the right to withdraw if the customer vehicle negligent or did not make installment payments as appropriate provisions.

If these efforts do not succeed, then the withdrawal of the vehicle can be done out of court or through a court. Court settlement have been selected for the weaknesses inherent in the judicial body to resolve disputes.

In this case required the consensus of both sides agreed to resolve it out of court. If a case can not be settled amicably by the parties litigant, a last resort that can be reached is begging settlement through the court.

\subsection{Suggestion}

Suggestions in this study are as follows:

- Financing agreement with fiduciary whose implementation through surrender fiduciary property rights committed by the debtor and the creditor should be able to provide benefits for both parties.

- Financing agreement with fiduciary who do should be based in good faith and in the event of problems should be done amicably through peace before the issue submitted to the court.

\section{Bibliography}

[1] Burhan Bungin, 2001. Metode Penelitian Sosial, Format-format Kuantitatif dan kualitatif.: Airlangga Unversity Press, Surabaya

[2] Dellyana, Shant, 1988, Konsep Penegakan Hukum. Liberty Yogyakarta

[3] E. Utrecht, 2002, "Pengantar Dalam Hukum Indonesia", Balai Buku Ichtiar, Jakarta.

[4] Marulak Pardede dan Badan Pembinaan Hukum Nasional Departemen Hukum dan Hak Asasi Manusia RI, 2008, Penelitian Hukum Tentang Implementasi Jaminan Fidusia Dalam Pemberian Kredit Di Indonesia, Jakarta

[5] Mukti Fajar ND dan Yulianto Achmad, 2010, Dualisme Penelitian Hukum Normatif \& Empiris, Pustaka Pelajar, Yogyakarta

[6] Nazir, Moh, 2013, Metode Penelitian, Bogor: Ghalia Indonesia. 
[7] Sutarno, 2005, Aspek-Aspek Hukum Perkreditan pada Bank, Alfabeta, Bandung.

[8] Ronny Hanitjo Soemitro, 1998, Metodologi Penelitian Hukum, Ghalia: Jakarta

[9] Suharsimi Arikunto, 2002, Prosedur Penelitian Suatu Pendekatan Praktek (Edisi Revisi V) Rineka Cipta:Yogyakarta.

[10] The Code of Penal (Penal Code).

[11] Act No. 42 of 1999 on Fiduciary

[12] Government Regulation No. 21 of 2015 regarding Registration Procedures and Fees Fiduciary Creation Deed.

[13] Act No. 48 of 2009 on Judicial Power

[14] Nurlia Latukau, Bambang Winarno, Bambang Sudjito Perlindungan Hukum Bagi Kreditor Atas Objek Jaminan Fidusia Yang Dibebani Fidusia Ulang Oleh Debitor Yang Sama. Master of Notary Journal Faculty of Law of Brawijaya University. Malang. 2017. 